\title{
The methodology of Neo-Austrian economics and its effect on behavioral finance
}

\author{
Mengdi Hao ${ }^{\mathrm{a}}$ \\ School College of Letters and Science, University of Wisconsin- Madison 53715, America. \\ ahaomengdi@163.com
}

Keywords: Neo-Austrian school; the theory of human behaviour; behavioural finance

\begin{abstract}
Austrian economics is a very important branch in the history of economic thought, and its proposition has many differences with the mainstream economic theory. On the basis of the inherited of the traditional Austrian economics architects' ideas, The Neo-Austrian Economics has put forward many profound insights of economics. In the context of human behaviour, this paper reviews the origin and methodology of Neo-Austrian school. And its effect on behavioural finance has been discussed.
\end{abstract}

\section{Introduction}

Since Adam Smith, economics has been through hundreds of years of research by several generations of economists. Many schools of thoughts have been created. On how to explain the operation of world economy and policy proposals, different school of thoughts have different explain which keeps competing. A revolutionary change in the development of economics is that the marginal revolution and the "methodology controversy". Since then, the era of classical economics had ended, and the modern economics began to develop. With the development, differentiations have occurred. The neoclassical economics has been developed, on the behalf of William Stanley Jevons, Leon Walras while the Austrian economics has been built on the behalf of Carl Menger, Bohm-Bawerk, Ludwig von Mises, and Friedrich Hayek. Both the Austrian economics and the neoclassical economics are all divided from the classical economics, and both participated in the marginal utility revolution [1]. However, among those school of thoughts involved in the revolution of marginal utility, the Austrian school sticks to the tradition of subjective value analysis which virtually on methodology became the third school of thought independent from the new classical economics and traditional sociology.

In 1871, the publication of Carl Menger's "Principles of Economics” marks the start of Austrian school. Under the development of the two faithful followers Bohm-Bawerk and Wesell, the Austrian school became innovation classical economics and has distinct features. Although it not become mainstream economics, Austrian school of economics still has important position in the history of economic thought, some of the important thoughts of the school have been absorbed by the mainstream economics. Mises, the founder of Neo-Austrian economics, inherited the traditional Austrian economics architects' ideas and put forward many profound insights of economics in the framework of human behavior [2]. Its research paradigm characterized by people's behavior also provides a theoretical basis for the development of behavioral finance.

\section{The origin and development of Neo-Austrian economics}

In " Principles of Economics ", Menger challenged the theory of labor value from the classical economics, systematically developed a subjective theory of value and price combining the marginal principle [3]. With respect to the manner of economic system operation, Menger has different opinions with neoclassical economics which became the basic hardcore of Austrian economics paradigm. Start from the "marginal revolution", Austrian school of economics have their own 
characteristics, destined to the Austrian school of economics is different from other school of economics.

Ludwig von Mises is the founder and spiritual leader of the modern Austrian school of economics. The publishing of "The Theory of Money and Credit” is the symbol of the born of NeoAustrian economic. Mises inherited the individualism and subjectivism method created from the founders of Austrian school of economics, and corrected the frailness of insist on the two methods of the later. After further development, the thoughts of Mises gradually formed a set of relatively complete theoretical system of people's behavior from which theoretical perspective the details of all aspects of economics are analyzed.

\section{The methodology of Neo-Austrian economics}

Austrian economics regard the economics as an integral part of human behavior which means that economics is a social science; it studies the relationship between people or between people and things. The main character in the economics research is people, not things; it is involved in a completely different subjective world and the physical world. The economic world is real field composed of human motivation, interest and purpose, it is not objective, but realistic. From the view of Austrian economics, the main task of economic science is to explain the world by the action of human. Therefore, if our task is to understand the world composed by human behaviors, we can only choose human behaviors to explain events. Only in this way, a consistent causality chain about economic things can be established.

\subsection{Individualism and subjectivism.}

As a theory about human behavior, economics also means individualism and subjectivism on its methodology. The individualism methodology Individualism methodology is to solve the questions that from what perspective economics should be use to explain social phenomena, start from the individual, or start from the collective? In this methodology, study social phenomena should from the perspective of individual behavior, while the social phenomenon is only the result of behavior of a single man. The methodology of individualism is the opposite of collectivism. The former argues that it should from individuals to the collective, while the latter believe that society as a whole has its own purpose and needs. Mises and hayek is firmly opposed to the methodology of collectivism. Mises pointed out that all behavior is the behavior of people, after the behavior of the individual members is excluded, and there would be no society reality. Hayek repeated that his individualism is from the point of methodological, not about social and political.

The methodology of individualism is closely related to the subjectivism; they are actually the two sides of the same piece of coin. Subjectivism requires economics to adopt the method and the position different from natural science. Economics not only analyzes the individual action, but also the objective results produced by the interaction of the countless personal action, which natural means that all economic categories are subjective. Since everyone is different, so there are no socalled objective economic laws. Hayek points out that the value related to the economic behavior can only illustrate by various human purpose and relevant ideas about these goals. Social science research is subject to the object. However, the nature of the object realized by subject is not objective exist; it's just subjective consciousness of the activities in the classification. Which means the law of social science is about the hypothesis people in the same environment under the same reaction. The subjectivity of the social science is according to personal subjective response to the economic phenomenon to classify economic phenomenon and find out the regularity.

\subsection{Research paradigm characterized by human behavior.}

Praxeology is a unique methodology of the Austrian school of economics. According to Mises, praxeology is a kind of ultimate assumptions of human behavior axiom system, it laid a solid theoretical basis for all social science which use human behavior as the research object. Praxeology provides the foundation of epistemology and methodology in economics. While Economics is a 
science that use fundamental axiom of human behavior and a few supporting justices to explain all market phenomenon.

Mises regards the special method using in economics as abstract construction method which is also the method of praxeology. The abstract construction method can abstract results produced by events from factors forming an important role for the events. This is the product of interpretation and ultimately derived from the behavior of the basic category.

Mises also introduced axioms and inference method in economic theory, thought that human behavior axiom is priori truth, not suffer the argument from experience. Specific theorem can't use experience truth to prove or disprove. The theorem of economics is not from the observation of the facts, but from deductive reasoning based on basic human behavior.

Mises also introduced time factor into the analysis of human behavior, he thought behavior means change which makes people notice the passage of time. He used the concept of time to against the mathematical and logical system and the application of econometrics and mathematics in economics.

\section{The effect of Neo-Austrian economics on behavioral finance}

In 2002, Daniel Kahneman and Vemon L. Srnith won the Nobel Prize in economics. It is the first time a psychologist who didn't receive serious economics training won the prize. After this, considering the factors of human behavior in the study of economics once again become a hot topic of researchers in economics.

Behavioral finance is a subject which study the financial phenomenon such as investment, savings, the price changes in a complex, incompletely rational market, is the combination of finance and psychology[4]. Behavioral finance is no longer confined to the narrow theoretical framework, but brings the social science theories and insights into the scope of investigation. It has returned to the starting point of finance analysis which is the human behavior[5]. The core concept of behavioral finance provides a psychology cornerstone for the rational economic analysis, which widens the vision of financial theory field and made the forecast to the actual phenomenon more accurate. As a young discipline, the deep research of behavioral finance has just started, hasn't form a tight structure system. Especially it hasn't found an independent economic theory as the basis of behavior finance. On the one hand, the behavior finance wants to do something unconventional or unorthodox, and get rid of the bondage of new classical economics; on the other hand, it falls into the trap of new classical economics on methodology. If behavioral finance wants to get rid of this dilemma, independent discipline status must be set up. Then comes to which can be the theoretical basis of behavioral finance.

In the psychology level, there are correlations between Neo-Austrian economics and behavioral finance. Different from neoclassical which rely too much on mathematical tool, the Neo-Austrian economics attach more importance to the role of psychological factors and influence in the study of economic phenomena. The Neo-Austrian economics free the economics from the narrow dead end, and put it in to the social philosophy level which takes people as main factor. And that is the biggest affect the Neo-Austrian economics gives to the behavioral finance. In the view of the Neo-Austrian economics, the study of the market economy should start from the psychology and human behavior. And with in-depth research on market mechanism, economic program, it has turn to the study of political philosophy, human interaction, social cooperation, etc. this is a typical theoretical cornerstone role for studying the finance in the background of the psychology, sociology and other related disciplines. Therefore, to keep enthusiasm of behavioral finance research, the independent discipline status must be set up.

\section{Conclusion}

In the eyes of some economists, the Austrian economics is just another new classical economics which hate math and advocate free market economy. But in fact, when comes to how economists look at the world and how to do their work, the Neo-Austrian economics interpreted an economics 
research objects and methods which are different from the new classical economics. In order to reveal the real causality behind economic phenomena, the Neo-Austrian economics describes a dynamic world with the human behavior. The Austrian school of economics attaches great importance to human behavior which extends the tradition of economics. However, the NeoAustrian economics belong to the part of the sciences of human action, and it is different with the "behavior" in the behavioral finance. Whether or not the behavioral finance can draw lessons from the Neo-Austrian economics ideas to promote its development will be a deeper research direction in the future. From the most profound sense, the Neo-Austrian economics is a radical and even a revolutionary reconstruction to economics.

\section{References}

[1]. Lachmann, L.M., From Mises to Shackle: an essay on Austrian economics and the kaleidic society. Journal of economic literature, 1976. 14 (1): p. 54-62.

[2]. Mises, L.v., Human action. 2006.

[3]. Menger, K., Principles of economics, trans. by James Dingwall \& Bert F. Housesits. Institute for Humane Studies. [RAM], 1871.

[4]. Barberis, N. and R. Thaler, A survey of behavioural finance. Handbook of the Economics of Finance, 2003. 1: p. 1053-1128.

[5]. Xia Ming, The Study of Behavioural Finance from the Subjective Perspective: The View of Austrian School. Economic R eview, 2015 (5): p. 154-160. 